\title{
HETEROGENEOUS FACE OF INDONESIAN MUSLIMS IN THE MIRROR OF POPULAR ISLAMIC PUBLICATION A New Model of Transmitting Teachings and Meeting the Need of Religion
}

Chairati Saleh

IAIN Sunan Ampel, Surabaya - Indonesia

Book Review

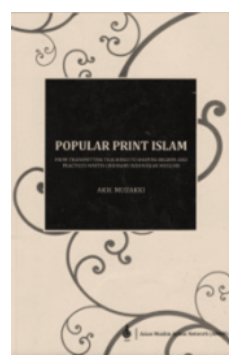

Book title : Popular Print Islam; From Transmitting Teachings to Shaping Beliefs and Practices witbin Ordinary Indonesian Muslims

Author : Akh. Muzakki

No. of Pages : $\quad$ vi +111

Year : 2011

Publisher : Asian Muslim Action Network

This book deals with the roles of popular print Islam, both in transmitting Islamic teachings and constructing beliefs and practices among current ordinary Indonesian Muslim. There are tendencies of contemporary Indonesian Muslim to move from the Islamic books devoted to Islamic boarding schools milieu called Kitab Kuning and intellectually critical Islamic books to popular print Islam with various book genres both in gaining a practical guide for life and transmitting Islamic teaching.

Unlike other researches which were more concerned with the publications on the pre-modern period and commonly focused on the field which had been purely on the intellectual content of and intellectual conflicts within the Islamic thinking, Muzakki's book more 
emphasizes on the popular Islamic books in the reform era and are commonly performed in a simple way "speak in the language of its people", handy and also are offering the practical solution for personal problems.

To examine this new trend, Muzakki begins with identifying same factors that contribute to the increase in publication of popular print Islam (Chapter 3), then drawing attention to the transmission of Islamic teaching to ordinary Indonesian (chapter 4), following by the description of the rising genres of popular Islamic books (chapter 5), then the roles of popular Islamic books in constructing beliefs and practices of current ordinary Indonesian Islam (chapter 6).

The book identifies three factors that contribute to the increase in publication of popular print Islam. First, the change of the political and publication climate in Indonesia after the fall of the Soeharto regime in 1998, from authoritarian and tight state control to the current situation characterized by liberalization, is significantly less state intervention, and gives more freedom of speech and expressions. It is well known that during New Order regime, people are restricted to have free public sphere and freedom of expression. Many media outlets, both secular and Islamic publications, were shut down by the government, such as Tempo, Editor, Detik (1994) and Sabili (1993).

Islamic publications benefit from the changed situation which has a guarantee to enable people to express their ideas more openly. They represent the importance and far-reaching media for delivering Muslim expression in Indonesia as well as they emerge as a business activity with a high economic prospect (p.13).

Second, as it happens in many countries, transition is often accompanied by anomalies, social unrest and tension among old and new elements. People continuously faced numerous social-political and economic problems. Regarding this situation, unresolved economic crisis has provided fertile soil for the increasingly marketable popular Islamic publications. In line with this condition, the Muslim community looks for practical solution for solving their own problems using "cultural-cum-belief system", instead of the previous model of political and economic problem-solving which has been undertaken by the state and even by the Muslim organization (p.14).

The third factor that contributes to the increase in popular Print Islam is the tendency of people who get to be bored with the publications which contain doctrinal contents and preach about too 
many dos and don'ts. People are more interested in books on religion which provide useful lessons from personal experiences and inspiring stories. This tendency is concluded from the result of interviewing with interviewing Carolina, the Promotion General of al-Hikmah publishing house of the Mizan group and library research (p.15).

Chapter 4 explores popularism and intellectualism as the two models of the tradition of production and consumption in transmitting Islamic teachings. Popular Islamic books are more oriented and segmented to popularism, namely ordinary people as actual audiences, while intellectualism is considered as educated people who only become postulated audience of popular print Islam. Sociologically, according to Muzakki, there are three differences between popularism and intellectualism within the production and consumption of religion: the way of approaching religion, the level of the need of religion, and the orientation of practicing religion. Regarding the way of approaching religion, popularism approaches Islam in a didactic way, perceiving it more as a practical guide for life, whereas intellectualism views religion more discursively by allowing any re-questioning of religious stipulation. In relation to the level of the need of religion, popularism provides people with certainty for their religious practices at a higher level than intellectualism. Regarding the aspect of the fulfilling of the material need for religion rather than fulfilling intellectual-cognitive needs, intellectualism is the other way around. Popular Islamic publications provide the kind of transmission of Islamic teachings which can be categorized as part of the popularism model.

Chapter five of this book specifically discusses about the rising genres of popular Islamic books from the 21th century, and the tendency of the decrease on the intellectually-critical Islamic books. Umi Kulsum states that since 2002 popular Islamic books have had a very good response from the market, such as La Tahzan written by Aidh Al-Qani and Ayat-ayat Cinta Novel by El-Shirazy. Qisthi press, the publisher of La Tabzan, admitted that he has been able to sell no less than 500,000 copies since its publication in 2005. Conversely, the intellectually-critical Islamic books dropped dramatically from previous years, particularly since 2000. Ahmad Fikri, the managing director of LKiS in Yogyakarta stated further on this matter, namely during 19931997, as one single title of the book - genre of intellectual-critical Islam-- could be printed three times a year with 3000 copies for a 
single edition, but lately, LKIS had published only 1,000 copies for each title and cannot be sold out within one year (P.34).

In this part, Muzakki also categories some genres of popular print Islam during 2005-2008 into six types, namely Islamic teen lit (a kind of popular Islamic printed book publication devoted and segmented to teenage consumers), Islamic kid lit (a genre of popular Islamic printed book publication devoted and segmented to consumers at childhood, including Islamic comic books, Islamic cartoon storybooks, and Islamic short storybooks, tarbiyat al-ummah literature (a kind of popular Islamic printed book publication aimed at developing ideas oriented to the development of da'wah or religious proselytizing and cohesion among Muslim communities), Islamic novel literature, Islamic how-to literature, and religious-cum-scientific books.

Furthermore, the chapter six of this book examines the roles of popular Islamic books in constructing beliefs and practices among ordinary Muslim community. There are three methods of how popular print publications, in various genres such as those described above, draw the attention of current ordinary Indonesian Muslim to meet their need of religion, namely "Islam through story", "Islam as a manual", and "Islam through medical-scientific explanation" (P.80).

By interviewing some readers of Islamic novel literature, Muzakki finds out the significance roles of "Islam through story" in transmitting and constructing beliefs and practices among youth Muslims. For instances is that both Shelly Tutupoho, a middle-aged female reader from Bandung and Anisa, a student of psychology in one of private universities in Yogyakarta admit that they are inspired by the story and the character within Novel Ayat-ayat Cinta regarding the way of choosing a partner and how to behave in an Islamic manner when they fall in love with someone. "I want my boyfriend to follow the characteristics of being a good Muslim boy like Fahri," Anisa said. In this case, the author strengthens his argument by borrowing Ricci's theoretical perspective of "Islam through story" which is considered greatly helps the attempts to formulate and construct Islamic beliefs within societies (P.81).

Similarly, "Islam as a manual" and "Islam through medicalscientific explanation" are also central to be methods of constructing Islamic traditions among ordinary Indonesian Muslim community. La Tahzan is one of the popular Islamic books that has a great influence on Muslim to deal the practical problems, while Terapi Salat Tahajud by 
Soleh becomes an exemplar of "Islam through medical-scientific explanation" in constructing Islamic practices among ordinary Muslim.

Overall, Popular Print Islam; From Transmitting teaching to Shaping Beliefs and Practices within Ordinary Indonesian Muslims, provides new insights into current Indonesian Muslim tradition in transforming the Islamic teachings as well as in facing and seeking the answers for their practical problems of life from their religion: a new tradition, which is influenced by the rise of popular Islamic publications, which leads to the signifying of the homogenous character of Indonesian Islam.

However, as the critical account of this book, it would be better if the author is able to explore more deeply --using framework analysis of discourse practice and social-cultural practice-- the ideological orientation of popular Islamic books which are widely spread in the market, as well as the reasons why readers select or choose one book, not the other. Thus, the ideology of the Muslim sub-group on Islamic teachings embedded in those popular Islamic books will be unveiled. It is also absurd that in the last paragraph of the book the author wrongly uses a particular word in reviewing and summarising his basic argument about the diversity of expressions in Indonesian Islam. Instead of making use of the word "heterogeneous" to refer to the essence of diversity, he comes with "homogeneous". [] 